\title{
Effectiveness of the Additional Feeding Program Using Combination of Green Bean Juice and Boiled Chicken Egg Toward Changes in Nutritional Status of Toddler Stunting in Pandeglang Regency
}

\author{
Catur Erty Suksesty \\ Midwifery Bachelor Degree \\ Program Health Science Faculty \\ Muhammadiyah University of \\ Tangerang \\ Tangerang Indonesia \\ catur_erty@y7mail.com
}

\author{
Hikmah \\ Midwifery Bachelor Degree \\ Program Health Science Faculty \\ Muhammadiyah University of \\ Tangerang \\ Tangerang Indonesia \\ hz.hikmah@gmail.com
}

\author{
Eka Mardiana Afrilia \\ Midwifery Bachelor Degree \\ Program Health Science Faculty \\ Muhammadiyah University of \\ Tangerang \\ Tangerang Indonesia \\ eka_afrilia@rocketmail.com
}

\begin{abstract}
Stunting is a condition where a child's height is much shorter than the height of other children at his age. Based on the Riskesdas in 2018 it is known that the prevalence of children under five with the height level of very short and short at $30.8 \%$. The highest problem of energy and protein deficits in Pandeglang Regency, with a prevalence above $70 \%$. Giving additional food is one of the strategies for supplementation in overcoming nutritional problems. Provision of Supplementary Feeding Combination of Green Bean Juice and Boiled Chicken Eggs are energy and protein-dense foods derived from ingredients that are easily obtained in the community at affordable prices. The purpose of this study was to determine the effectiveness of the combination supplementary feeding program to change the nutritional status of stunting children. The population in this study were toddlers aged 12-59 months who suffered stunting in Pakuluran village Pandeglang District. The technique used in sampling was purposive sampling with the number of 24 children under five who were given a combination feeding intervention for 30 days. This research is a quasiexperimental study with a one group pre and post test desing design which aims to determine whether there is an effectiveness of supplementary feeding combinations to improve the nutritional status of stunting children. The design of the analysis using the T test and Chi-Square test was obtained for $45.8 \%$ of children under five who underwent nutritional improvement after being given a combination of additional foods. There is a strong relationship between the intervention carried out on changes in toddler weight with a value of $p<0.05$. However, there is no significant difference in changes in toddler height with a value of $p>0.05$.
\end{abstract}

Keywords: nutritional status, provision of supplementary feeding, stunting

\section{INTRODUCTION}

One of the ways to achieve success in health development is by maintaining good nutrition. Children under-five years old, schoolage children, and pregnant women are prone to poor nutritional status, and thus they need special attention due to the negative effects of malnutrition.

Based on the health research in 2018, the prevalence of toddlers who were severely stunted and stunted was at about $30.8 \%$, while the prevalence of toddlers who were severely thin and thin was around $10.2 \% .{ }^{[1]}$ Stunting (dwarfism) is a condition in which a toddler has less length or height compared to his or her normal age. This condition is measured by length or height that is above minus two standard deviations below the median on the World Health Organization standards. Stunting is chronic nutritional problems caused by many factors such as socioeconomic conditions, nutritional status of women during pregnancy, morbidity in infants, and nutritional deficiency (malnutrition) in infants. As a result, stunting toddlers will experience some difficulties in achieving his or her optimal physical and cognitive development. [1][2]

The main nutritional problem in Banten is chronic nutritional problems and the prevalence of stunting (stunted and severely stunted) in toddlers was still high about more than a hundred cases. Besides, all districts or cities in Banten also have acute nutritional problems. The prevalence of toddlers experiencing thinness was more than $10 \%$ in general, and the prevalence of family with protein-energy malnutrition was quite high with an average of above $50 \%$. This illustrates that the nutrition problems in Banten need concern from the local government. The highest problem of protein-energy malnutrition is in Pandeglang, with the prevalence of above 70\%. [2][3]

Applying optimal feeding practices is very important to maintain the survival, growth, and development of children. One of the lowest rates in Indonesia, about $32 \%$ of babies are breasted exclusively 
in the first six months of their lives. The prevalence of malnutrition is relatively high, including in urban areas. Around $16 \%$ of babies were born with low weight, and one-third of under-five children experience stunting (having a lower height compared to their ages) in 2013.[1][3]

Supplementary feeding especially for vulnerable groups is one of the strategies to overcome nutritional problems. Based on Total Diet Survey (SDT) data in 2014, the number of energy requirements of more than half of underfive children $(55.7 \%)$ was less than the recommended number of energy requirements in the Energy Adequacy Ratio (AKE). Providing supplementary feeding to infants is one of the efforts to meet the nutritional needs of infants, thus babies can achieve optimal growth and development. Growth is a series of activities consisting of measurement of physical growth and individual development in the community to improve children's health status, development, and quality of life. Measured by weight, a growth of a baby goes very quickly related to the problem of large growth, number, size or dimensions of the cell level, and baby's organs.[4][5]

To increase the nutritional content, local food containing protein and vitamins becomes an alternative to supplementary food as it is easily got. One of the local foodstuffs with nutrientdense food is mung beans (Phaseolus Radiatus) which have nutritional content including carbohydrates (62-63\%) as the largest component of mung beans. The fat content of (fresh) mung beans is $0.7-1 \mathrm{~g} / \mathrm{kg}$ consisting of $73 \%$ of unsaturated fat and $27 \%$ of saturated fat, thus it is safe for human consumption. Based on the amount, protein occupies the second main position. Mung beans contain protein (20-25\%), and raw mung beans has protein digestibility

$(77 \%) .[6][7][8]$

Besides mung beans, one of the protein sources needed by the body is eggs. Egg nutrition consists of water $(73.7 \%)$, protein $(12.9 \%)$, fat $(11.2 \%)$, and carbohydrate $(0.9 \%)$. Indonesians generally meet their protein needs by consuming eggs since it has a beneficial effect in human life, and therefore eggs are highly recommended for children who are growing up.[5][9]

Based on the cases above, it is necessary to conduct a research entitled "The effect of

Supplementary Feeding Program (Food Combinations) towards Changes in Nutritional Status of Stunting Toddlers".

\section{METHOD}

This research was a quasi-experimental with a onegroup pretest-posttest design to determine the effect of supplementary feeding program of food combinations to improve the nutritional status of stunting children. This research was conducted in Pakuluran, Koroncong,
Pandeglang, Banten in June 2019. The subjects were all stunting children about 24 toddlers.

The data including the toddler's identity was collected using a questionnaire. The researcher started pretest by weighing and measuring toddlers' height using scales.

A combination of supplementary food such as mung bean juice and boiled chicken eggs was given to toddlers for 30 days at mealtimes. Each toddler got 280 $\mathrm{ml}$ of formulated mung beans and one boiled chicken egg. Posttest was carried out by re-evaluating toddlers' weight and height after the 30th day using weight and height scale. The data was analyzed using quantitative method by T-test to determine the effectiveness of food combinations of mung bean juice and boiled chicken eggs on changes in nutritional status of stunting toddlers.

\section{RESULTS AND DISCUSSION}

\section{Characteristics of Respondents and Research Subjects}

Male and female toddlers (50\% each) aged 12 to 60 months were observed. Toddlers who were not exclusively breastfed were greater than those who were exclusively breastfed (58.3\%). Moreover, toddlers having a history of Low Birth Weight (LBW) were $6 \%$. Surprisingly, only one mother $(4.2 \%)$ was in a higher level of education.

Table 1. Characteristics of research subjects

\begin{tabular}{|c|c|c|}
\hline \multirow[t]{2}{*}{ Research Subject } & \multicolumn{2}{|c|}{ Total } \\
\hline & $\mathrm{N}$ & $\%$ \\
\hline \multicolumn{3}{|l|}{ Age } \\
\hline 12-36 Months & 12 & 50,0 \\
\hline 37-60 Months & 12 & 50,0 \\
\hline \multicolumn{3}{|l|}{ Gender } \\
\hline Male & 12 & 50,0 \\
\hline Female & 12 & 50,0 \\
\hline \multicolumn{3}{|l|}{$\begin{array}{l}\text { History of Exclusive } \\
\text { Breastfeeding }\end{array}$} \\
\hline Yes & 10 & 41,7 \\
\hline No & 14 & 58,3 \\
\hline \multicolumn{3}{|l|}{$\begin{array}{l}\text { History of Low } \\
\text { Birth Weight }\end{array}$} \\
\hline yes & 6 & 25,0 \\
\hline No & 18 & 75,0 \\
\hline Mother's Education High & 1 & 4,2 \\
\hline Low & 23 & 95,8 \\
\hline Total & 24 & 100 \\
\hline
\end{tabular}

Tabel 1, Male and female toddlers (50\% each) aged 12 to 60 months were observed. Toddlers who were not exclusively breastfed were greater than those who were exclusively breastfed (58.3\%). Moreover, toddlers having a history of Low Birth Weight (LBW) were $6 \%$. Surprisingly, only one mother $(4.2 \%)$ was in a higher level of education 


\section{Nutritional Status of Research Subjects before Intervention}

Underweight nutritional status research subjects was $62.5 \%$ based on weight/age category and underweight nutritional status was $62.5 \%$ based on weight/height category. All research subjects (100\%) were categorized as short in their nutritional status based on height/age category.

Table 2. Nutritional status of research subjects before intervention

\begin{tabular}{|l|l|c|}
\hline Research Subject & & Total \\
\cline { 2 - 3 } & $\mathrm{n}$ & $\%$ \\
\hline $\begin{array}{l}\text { Weight/Age } \\
\text { Good Nutritional Status }\end{array}$ & 9 & \\
\hline Poor Nutritional Status & 15 & 37,5 \\
\hline $\begin{array}{l}\text { Weight/Heigt } \\
\text { Thin }\end{array}$ & 15 & 62,5 \\
\hline Normal & 9 & 62,5 \\
\hline Body Heigt/age & & 37,5 \\
\hline Short & 24 & 100 \\
\hline Normal & 0 & 0 \\
\hline Total & 24 & 100 \\
\hline
\end{tabular}

\section{Nutritional Status of Research Subjects after} Intervention

After being given an intervention by distributing supplementary food (a combination of mung bean juice and boiled chicken eggs) to the research subjects for 30 days, it was found that there were changes in nutritional status in toddlers.

Good nutritional status increased up to $54.2 \%$ and toddlers with normal nutritional status increased up to $45.8 \%$. It was also found that 2 toddlers was in normal nutritional status based on height/age category.

Table 3: Nutritional Status after an Intervention

\begin{tabular}{|l|l|l|}
\hline Research Subject & & Total \\
\hline $\begin{array}{l}\text { Weight/Age } \\
\text { Good Nutritional Status }\end{array}$ & $\mathrm{n}$ & $\%$ \\
\hline \multicolumn{1}{|c|}{ Poor Nutritional Status } & 13 & 54,2 \\
\hline Weight/Height Thin & 11 & 45,8 \\
\hline Normal & 13 & 54,2 \\
\hline $\begin{array}{l}\text { Body Height/Age } \\
\text { Short }\end{array}$ & 11 & 45,8 \\
\hline Normal & 22 & 91,7 \\
\hline Total & 2 & 8,3 \\
\hline
\end{tabular}

4. Combinations of Supplementary Feeding of Mung Bean Juice and Boiled Chicken Eggs on Changes in Nutritional Status of Stunting Toddlers

Table 4. The Relationship between Combinations of Supplementary Feeding and Changes in Nutritional Status of Stunting Toddlers

\begin{tabular}{|c|l|c|c|}
\hline $\begin{array}{l}\text { Prete and } \\
\text { Posttest }\end{array}$ & $\mathrm{N}$ & Correlation & Sig \\
\hline $\begin{array}{c}\text { Weight/ } \\
\text { Age }\end{array}$ & 24 & -.497 & .014 \\
\hline $\begin{array}{c}\text { Weight/ } \\
\text { Height }\end{array}$ & 24 & -.367 & .078 \\
\hline $\begin{array}{c}\text { Height/ } \\
\text { Age }\end{array}$ & 24 & .00 & .00 \\
\hline
\end{tabular}

Table 5. The Effects of Supplementary Feeding (Food Combinations) towards Changes in Nutritional Status of Stunting Toddlers

\begin{tabular}{lcccccc}
\hline \multicolumn{1}{c}{$\begin{array}{c}\text { Pretest and } \\
\text { Posttest }\end{array}$} & Mean & $\begin{array}{c}\text { Std. } \\
\text { Deviat } \\
\text { ion }\end{array}$ & $\begin{array}{c}\text { Std. } \\
\text { Error } \\
\text { Mean }\end{array}$ & t & df & Sig. \\
\hline Weight/Age & -.167 & .868 & .177 & -.941 & 23 & .357 \\
\hline Weight/ & & & & & & \\
Height & -.083 & .830 & .169 & -.492 & 23 & .627 \\
\hline Body & & & & - & & \\
Height/Age & -.083 & .282 & .058 & 1.44 & 23 & .162 \\
& & & & 6 & & \\
\hline
\end{tabular}

Table 4 and 5 show that supplementary feeding of mung bean juice and boiled chicken eggs had a positive tendency to improve the nutritional status of under-five children based on weight/age and weight/height, but it did not influence significantly on changes in nutritional status based on height/age category.

Supplementary Feeding (food combinations) for stunting toddlers aims to provide a high intake, especially high in plant and animal protein. This should be done to provide changes in nutritional status of stunting children.

Stunting is a condition of growth disorders experienced by children due to malnutrition for a long time. Thus, stunting children are not only short for their ages but their bodies and brains. Protein deficiency in stunting toddlers will worsen the toddler's nutritional status and will inhibit the process of growth and brain development. Stunting problems illustrate the presence of chronic nutritional problems influenced by the nutrition of the prospective mother, the fetus, infancy including illnesses during infancy. In this research, 
(45.8\%). The statistic results showed combinations of supplementary food such as mung bean juice and boiled chicken eggs had a positive tendency to improve nutritional status of under-five children based on a category of weight/age and weight/height, yet it did not significantly influence changes in nutritional status based on a category of height/age. At this point, there were 2 toddlers having changes in nutritional status from stunting to normal. Providing supplementary food will provide optimal intake, especially protein intake. It is suggested that information or education about the importance of improving nutritional status of stunting toddlers is necessary to help improving physical growth and brain development.

\section{REFERENCES}

[1] K. K. B. P. dan P. K, Hasil Utama Riset Kesehatan Dasar. Kementrian Kesehatan Republik Indonesia. 2018.

[2] TNP2K, “100 Kabupaten/kota prioritas untuk penanganan anak kerdil (stunting).," 2017. .

[3] WHO, "Nutrition landscape information systems (NLIS): Country profiel indicators Interpretation Guide. Nutrition Landacape Information System, 1-51,” 2010. [4] Kemenkes RI, "Profil Kesehatan Republik Indonesia Tahun 2009.," 2009. [Online]. Available: $\quad$ www.depkes.go.id/.../profilkesehatanindonesia/profil-kesehatanindonesia2009.pdf\%0A\%0A.

[5] L. Ratna Noer, E., Rustanti, N., \& Elvizahro, Karakteristik makanan pendamping balita yang disubstitusi dengan tepung ikan patin dan labu kuning. 2014.

[6] J. C. De Lange, "Factors contruting to malnutrition in children 0-60months admitted to the hospital in Northern Cape," pp. 8-216, 2010 .

[7] J. I. C. Halim, L. A., Warouw, S. M., \& Manoppo, "Hubungan Faktor-Faktor

Risiko dengan Stunting pada Anak Usia

3-5 Tahun di TK/PAUD Kecamatan Tumintang," pp. $1-8,2018$.

[8] M. Hadiriesandi, Evaluasi Program Pemberian Makanan. 2016.

[9] I. Reply, "BEHAVIOUR THERAPY," Br. J. Psychiatry, pp. 1009-1010, 1965.

After distributing supplementary food in combinations with plant and animal proteins, toddlers had good nutritional status $(54.2 \%)$ and malnutrition
[10] Iskandar., "Pengaruh Pemberian Makanan Tambahan Modifikasi Terhadap Status Gizi 
Balita( Effect of supplementary feeding modification on nutritional status of toddler )," 2017.

[11] M. Aridiyah, F. O., Rohmawati, N., \& Ririanty, "Faktor-faktor yang Mempengaruhi Kejadian Stunting pada Anak Balita di Wilayah Pedesaan dan Perkotaan (The Factors Affecting Stunting on Toddlers in Rural and Urban Areas)," E-Jurnal Pustaka Kesehatan, vol. 3(1), pp. $163-170$.

[12] R. P. D. Swarinastiti, G. Hardaningsih, "DOMINASI ASUPAN PROTEIN NABATI SEBAGAI FAKTOR RISIKO STUNTING ANAK USIA 2-4 TAHUN," vol. vol. 7, no. 02, pp. 1470 1483.

[13] E. S. and R. Machmud, "Artikel Penelitian Faktor-Faktor yang Berhubungan dengan Kejadian Stunting pada Anak Usia 24-59 Bulan di Wilayah Kerja Puskesmas Andalas Kecamatan Padang Timur Kota Padang Tahun 2018," vol. Vol.07, no. 02, pp. 275-284,2018 